\title{
ALTERNATIVE TO THE INVERTED "Y" INCISION IN SCOLIOSIS SECONDARY TO MYELOMENINGOCELE
}

\author{
ALTERNATIVA À INCISÃO EM "Y" INVERTIDO PARA ESCOLIOSE SECUNDÁRIA PARA \\ MIELOMENINGOCELE
}

\section{ALTERNATIVA A LA INCISIÓN EN "Y" INVERTIDO EN ESCOLIOSIS SECUNDARIA A MIELOMENINGOCELE}

\author{
Diego Veiga Bezerra ${ }^{1,2,3}$, Luis Eduardo Munhoz da Rocha², Dulce Helena Grimm², Carlos Abreu de Aguiar², Luiz Müller Ávila², Fernando Soccol ${ }^{1,2,3}$ \\ 1. Hospital Evangélico de Curitiba, Curitiba, PR, Brazil. \\ 2. Hospital Infantil Pequeno Príncipe, Curitiba, PR, Brazil \\ 3. Hospital São Vicente de Curitiba, Curitiba, PR, Brazil.
}

\begin{abstract}
Objective: To evaluate the healing of the modified inverted "Y" incision in patients with scoliosis due to myelomeningocele. Methods: Retrospective study through medical records review of patients with myelomeningocele surgically treated with a modified inverted "Y" approach between January 2013 and December 2015. Results: We analyzed the medical records of six patients. Two patients progressed with skin complications in the immediate postoperative period and only one of them required surgical intervention for debridement and suturing. In another patient, it was necessary to perform two surgical reviews due to material failure without skin complications in these interventions. Conclusions: The modified inverted " $Y$ " technique is a great alternative to traditional incision and inverted "Y" because it has good results in patients with spina bifida associated with poor skin conditions treated surgically for correction of spinal deformities. Level of Evidence IV; Case series.
\end{abstract}

Keywords: Myelomeningocele; Scoliosis/etiology; Scoliosis/surgery.

\section{RESUMO}

Objetivo: Avaliar a cicatrização da modificação da incisão em "Y" invertido em pacientes com escoliose decorrente de mielomeningocele. Métodos: Estudo retrospectivo, mediante revisão de prontuários dos pacientes portadores de mielomeningocele, tratados cirurgicamente por um acesso cirúrgico modificado do "Y" invertido, entre janeiro de 2013 e dezembro de 2015. Resultados: Foram analisados os prontuários de seis pacientes. Dois pacientes evoluíram com complicações de pele no pós-operatório imediato, apenas em um deles foi necessária intervenção cirúrgica para debridamento e sutura. Em outro paciente foi necessário realizar duas revisões cirúrgicas, devido a quebra do material, sem ocorrer complicações de pele em todas as abordagens. Conclusão: A variação da técnica em "Y” invertido é uma ótima alternativa à incisão tradicional e ao "Y" invertido, por apresentar bons resultados em pacientes com espinha bífida associada às condições de pele ruins, tratados cirurgicamente para correção de deformidades da coluna vertebral. Nível de evidência IV ; Série de casos.

Descritores: Mielomeningocele; Escoliose/etiologia; Escoliose/cirurgia.

\section{RESUMEN}

Objetivo: Evaluar la cicatrización de la incisión en "Y" invertida modificada en pacientes con escoliosis derivada de mielomeningocele. Métodos: Estudio retrospectivo mediante revisión de registros médicos de pacientes con mielomeningocele tratados quirúrgicamente por acceso quirúrgico en "Y" invertida modificada entre enero de 2013 y diciembre de 2015. Resultados: Se analizaron los registros médicos de seis pacientes. Dos pacientes desarrollaron complicaciones de piel en el postoperatorio inmediato y sólo en uno de ellos fue necesaria intervención quirúrgica para desbridamiento y sutura. En otro paciente fue necesario realizar dos revisiones quirúrgicas debido al quiebre del material, sin que ocurrieran complicaciones cutáneas en esas intervenciones. Conclusiones: La técnica en "Y" invertida modificada es una excelente alternativa a la incisión tradicional y la "Y" invertida por demostrar buenos resultados en pacientes con espina bífida asociada a malas condiciones cutáneas tratados quirúrgicamente para corrección de deformidades de la columna vertebral. Nivel de evidencia IV; Serie de casos.

Descriptores: Mielomeningocele; Escoliosis/etiología; Escoliosis/cirugía.

\section{INTRODUCTION}

Myelomeningocele is a medical condition originating from a defect in the closure of the neural tube that occurs at around the 3rd or 4th week of the embryonic period. ${ }^{1}$ The damage to the spinal cord and peripheral nerves is evident at birth and irreversible, even when surgical closure is performed in the immediate postnatal period. The neurological damage can lead to several orthopedic changes, among them scoliosis due to paralysis, this being the main cause of the high prevalence, which is determined by the motor level. ${ }^{2-4}$ The prevalence of scoliosis in this group of patients ranges from 23 to $88 \%$, with $88 \%, 81 \%$, and $23 \%$ at the thoracic, upper lumbar, and lower lumbar levels, respectively. ${ }^{4,5,6}$ This deformity can have direct impact on patient quality of life and, when neglected, usually makes it difficult for them to adapt to a sitting position and predisposes them to pressure ulcers and respiratory compromise. ${ }^{7,8}$

The goal of surgical treatment of deformity in patients with 
myelomeningocele is to correct the deformity, leveling the pelvis with instrumentation and arthrodesis to create stability and achieve trunk compensation. . $^{2,9,10}$

Complications related to the healing of the traditional medial longitudinal incision for the correction of deformities are frequent, mainly because these patients have poor skin coverage due to scarring from previous interventions for correction of myelodysplastic defects, as well as from flap rotations and second intention healing. Several incisions have been described as alternatives, among them the double incision and Mayfield's inverted $Y$ incision, 3,8 which we used in several patients, though with several issues with the healing of the skin at the apex of the $Y$ and unplanned revisions due to CSF fistulae caused by lesions of the dura mater because of dysraphism and scarring from birth defect correction.

In 1981, Mayfield developed a skin incision aimed at minimizing the occurrence of these complications with maximum exposure of the deformity for its correction, whereby he made an inverted $Y$ incision in order to spare the regions of skin unfavorable to a new approach. Something that caught his attention was the possibility of necrosis of the skin at the angle where the three branches of incision intersect, ${ }^{3}$ a condition observed in several of our patients treated via this approach.

The objective of this study is to describe a surgical access for patients with scoliosis secondary to myelomeningocele that presents fewer complications related to the healing of the wound that those described in the literature.

\section{METHODS}

\section{Sample}

We used a modification of the inverted $Y$ surgical approach in six patients with indications of surgical treatment for scoliosis secondary to myelomeningocele, but whose skin was in too poor a condition for the traditional incision.

\section{Inclusion criteria}

- Having myelomeningocele;

- Having scoliosis due solely to myelomeningocele;

- Having undergone corrective surgical treatment for scoliosis using a modification of the inverted $Y$ approach;

- Having the details of immediate postoperative and outpatient follow-up available;

- Having been in follow-up for a minimum of a year

\section{Exclusion criteria}

- Having scoliosis of any other type or cause other than myelomeningocele;

- Having been submitted to a type of incision other than the modified inverted $Y$;

- Not having adequate information in their medical records for data collection.

\section{METHODS}

We conducted a retrospective study of patients with spinal deformity resulting from myelomeningocele whose skin was in too poor a condition to undergo the traditional posterior approach. These patients were operated by the same lead surgeon from January 2013 to December 2015 using a modification of the inverted $Y$ approach and followed-up for a minimum of 12 months. The progression of the healing of this incision, as well as of any complications, such as necrosis, suture dehiscence, infection, and CSF fistula, and the final healing and resolution were evaluated.

The study was analyzed and accepted by the Institutional Review Board of the institution were the work was conducted as identification number 49246515.1.0000.0097.

All the patients included signed the Informed Consent Form in accordance with CNS/MS Resolution 196/96.
The incision used consists of a median longitudinal incision in the area of normal skin in the paravertebral region at the level of the pedicle and transverse processes of one side and a longitudinal incision lateral to the dysraphism, maintaining an intact proximal island of skin measuring approximately four centimeters. (Figure 1)

\section{RESULTS}

Six patients met the inclusion criteria and their data were analyzed more closely in Table 1. Patient age at the time of surgery ranged from 9 to 17 years. Four of the patients were female and two were male. They presented scoliotic spinal deformities with Cobb angles ranging from 65 to 126 degrees and the apices of the curves were located between T8 and T11. A modified inverted $Y$ approach was used in all patients, achieving corrections of from 51 to $76 \%$ in the immediate postoperative period.

All patients were followed-up for at least one year and their informed consent forms were signed by their parents or legal guardians.

Two patients had skin complications in the immediate postoperative period, one of them with a small dehiscence of the sutures that did not require reattachment and the other with dehiscence and marginal necrosis in the convex region of the lumbar curve (middle third of the incision) that required two surgical procedures for debriding and suturing. (Table 2)

One patient underwent two arthrodesis revisions for rod breakage due to pseudoarthrosis. There were no skin complications in the healing of the wounds in any of the approaches.

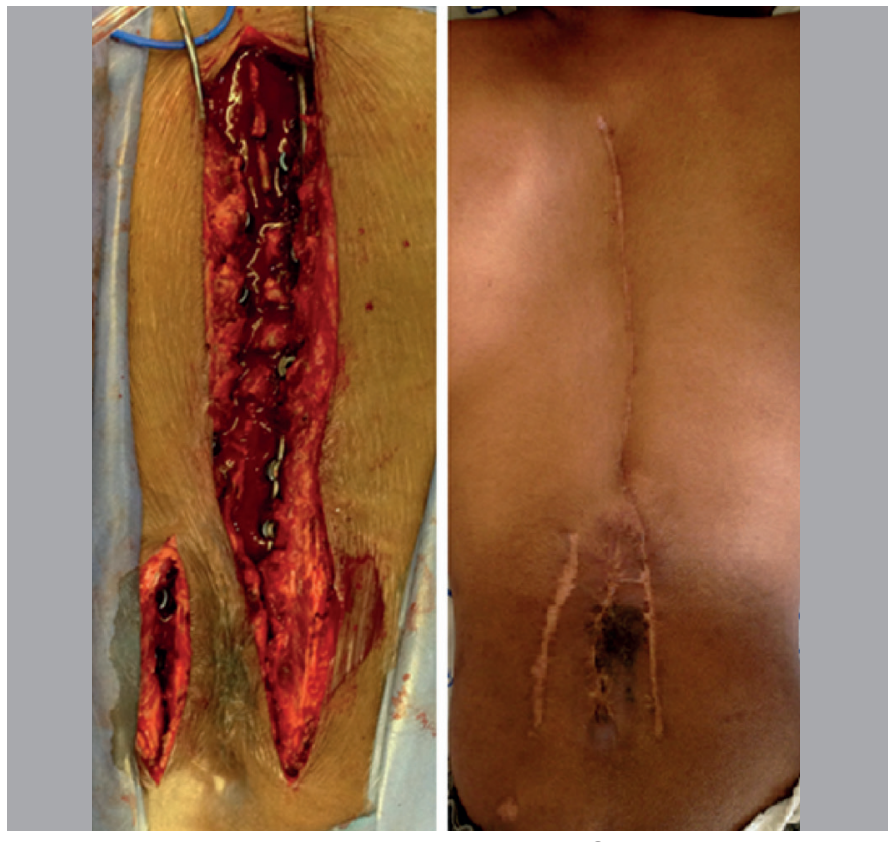

Figure 1. Modification of the inverted $Y$ incision. On the left: intraoperative view. On the right: Final aspect of healing.

Table 1. Patient clinical data.

\begin{tabular}{c|c|c|c|c|c|c}
\hline & Patient 1 & Patient 2 & Patient 3 & Patient 4 & Patient 5 & Patient 6 \\
\hline $\begin{array}{c}\text { Sex } \\
\begin{array}{c}\text { fge at time } \\
\text { of surgery }\end{array}\end{array}$ & Female & Female & Male & Male & Female & Female \\
\hline $\begin{array}{c}\text { Preoperative } \\
\text { curve }\end{array}$ & $\begin{array}{c}126 \\
\text { degrees }\end{array}$ & $\begin{array}{c}110 \\
\text { degrees }\end{array}$ & $\begin{array}{c}71 \\
\text { degrees }\end{array}$ & $\begin{array}{c}65 \\
\text { degrees }\end{array}$ & $\begin{array}{c}86 \\
\text { degrees }\end{array}$ & $\begin{array}{c}114 \\
\text { degrees }\end{array}$ \\
\hline $\begin{array}{c}\text { Postoperative } \\
\text { curve }\end{array}$ & $\begin{array}{c}30 \\
\text { degrees }\end{array}$ & $\begin{array}{c}26 \\
\text { degrees }\end{array}$ & $\begin{array}{c}26 \\
\text { degrees }\end{array}$ & $\begin{array}{c}31 \\
\text { degrees }\end{array}$ & $\begin{array}{c}25 \\
\text { degrees }\end{array}$ & $\begin{array}{c}60 \\
\text { degrees }\end{array}$ \\
\hline $\begin{array}{c}\text { Correction } \\
\text { degears }\end{array}$ & $76 \%$ & $63 \%$ & $52 \%$ & $71 \%$ & $51 \%$ \\
\hline Curve apex & T9-T10 & T9 & T8-T9 & T10 & T11 & T11 \\
\hline
\end{tabular}


Table 2. Types of complications.

\begin{tabular}{c|c|c}
\hline Suture dehiscence & $2 / 8$ & $25 \%$ \\
\hline Marginal necrosis & $1 / 8$ & $12.50 \%$ \\
\hline Infection & $0 / 8$ & $0 \%$ \\
\hline Fistula & $0 / 8$ & $0 \%$ \\
\hline
\end{tabular}

\section{DISCUSSION}

Postoperative complications occur in more than $20 \%$ of surgical corrections of spinal deformities in patients with myelomeningocele, mainly related to the healing of the surgical wound, infection, and pseudoarthrosis.

In a case series of 18 patients, Garg et al. observed 13 who had some complication, 7 of which required revision. The most frequently encountered complications in their study were pseudoarthrosis in five patients, deep infection in four, and delayed closure of the surgical wound in three patients. ${ }^{9}$

Geiger, in his article published in 1999, dealt with postoperative complications in myelodysplastic patients operated for scoliosis from both posterior and double-approach accesses and Harrington and Cotrel-Dubousset type instrumentation and reported that 19\% of complications were related to wound healing issues. ${ }^{11}$ Niall had primary healing problems in the surgical wounds of 13 out of 24 patients, six of which involved late exposure of the material from pressure sores. ${ }^{12}$

In 2011, Altiok analyzed the surgical outcomes in a series of 21 cases of operated patients with skin issues in the topography of the surgical incision, five of whom had problems with the healing of the surgical wound. ${ }^{13}$

In 2014, Khoshbin published a study of long-term follow-up comparing surgical and non-surgical treatment in this population. In the patients who underwent surgery, he also noted a high prevalence of complications including infection, CSF fistula, failure of the material, and others not related to the skeletal system. ${ }^{10}$
In his work, Mayfield was the first to describe the use of the inverted $Y$ incision in patients with poor skin conditions for the correction of spinal deformity. He obtained good surgical outcomes and good progression of the surgical scarring, but this approach was used in only three patients. ${ }^{3}$ Odent et al. also reported the use of the inverted $Y$ without complications related to the healing of the skin, however, their sample was small and they also used single and double longitudinal approaches without noting which was used in each patient. ${ }^{8}$

When we indicated the use of the incision we have described, we had already anticipated the high risk of skin complications associated with the traditional incision, so the indication was more appropriate, a fact that was confirmed when we analyzed the progression of wound closure in our patients. We achieved a skin complication rate of around $25 \%$ when we consider that we performed eight surgical procedures in the six patients. The complications we encountered were easily resolved spontaneously or with simpler surgical procedures.

The correction that we obtained was from 52 to $76 \%$, quite similar to the results of other studies, indicating that the modification to the surgical approach allowed good spinal exposure and deformity correction. ${ }^{11,14}$

\section{CONCLUSION}

The variation of the inverted $Y$ technique is an excellent alternative to the traditional incision and the Mayfield inverted $Y$ as it presents good results in patients with spina bifida associated with poor skin conditions treated for the correction of spinal deformities.

All authors declare no potential conflict of interest related to this article.

CONTRIBUTION OF THE AUTHORS: Each author made significant individual contributions to this manuscript. LEMR (0000-0002-1042-2886) ${ }^{\star}$, a surgeon, contributed with the cases, the analysis, and the final review of the text. DHG (0000-0002-1083-3677)*, CAA (0000-0003-4310-6537) ${ }^{\star}$, LMA (0000-0002-6244-8703)*, DVB (0000-0003-0044-8078)*, and FS (0000-0003-3219-7824)*, all surgeons, contributed with the bibliographical review, writing of the manuscript, and final review of the article. ${ }^{\star}$ ORCID (Open Researcher and Contributor ID).

\section{REFERENCES}

1. Blencowe $\mathrm{H}$, Cousens $\mathrm{S}$, Modell B, Lawn J. Folic acid to reduce neonatal mortality from neural tube disordrs. Int J Epidemiol. 2010;39 Suppl 1:1110-21.

2. Karol LA, King E. The orthopaedic management of myelomeningocele. Operative techniques in plastic and reconstructive surgery. 2000;7(2):53-9.

3. Mayfield JK. Severe spine deformity in myelodysplasia and sacral agenesis: an aggressive surgical approach. Spine (Phila Pa 1976).1981;6(5):498-509.

4. Canavese F, Rousset M, Gledic B, Samba A, Dimeglio A. Surgical advances in the treatment of neuromuscular scoliosis. World J Orthop. 2014;5(2):124-33.

5. Piggot $\mathrm{H}$. The natural history of scoliosis in children with myelodysplasia. J Bone Joint Surg Br. 1980;62-B(1):54-8.

6. Guille JT, Sarwark JF, Sherk HH, Kumar SJ. Congenital and developmental deformities of the spine inchildren with myelomeningocele. J Am Acad Orthop Surg. 2006;14(5):294-302.

7. Patel J, Walker J, Talwalkar VR, Iwinski HJ, Milbrandt TA. Correlation of spine deformity, lung function, and seat pressure in spina bifida. Clin Orthop Relat Res. 2011;469(5):1302-7.

8. Odent T, Arlet V, Ouellet J, Bitan F. Kyphectomy in myelomeningocele with a modifed
Dunn-McCarthy technique followed by an anterior inlayed strut graft. Eur Spine J. 2004:13(3):206-12.

9. Garg S, Oetgen M, Rathjen K, Richards BS. Kyphectomy improves sitting and skin problems in patients with myelomeningocele. Clin Othop Relat Res. 2011;469(5):1279-85.

10. Khoshbin A, Vivas L, Law PW, Stephens D, Davis AM, Howard A, et al. The Longterm outcome of patients treated operatively and non-operatively for scoliosis deformity secundary to spina bifida. Bone Joint J. 2014;96-B:1244-51.

11. Geiger F, Parsch D, Carstens $C$. Complication of scoliosis surgery in children with myelomeningocele. Eur Spine J. 1999;8(1):22-6

12. Niall DM, Dowling FE, Fogart EE, Moore DP, Goldberg C. Kyphectomy in children with myelomeningocele: a long-term outcome study. J Pediatr Orthop. 2004;24(1):37-44

13. Altiok H, Finlayson $\mathrm{C}$, Hassani S, Sturm P. Kyphectomy in children with myelomeningocele. Clin Orthop Relat Res. 2011;469(5):1272-8.

14. Modi HN, Suh SW, Yang JH, Cho JW, Hong JY, Singh SU, et al. Surgical complication in neuromuscular scoliosis operated with posterior only approach using pedicle screw fixation. Scoliosis. 2009;4:11X. 